\title{
Investigation of the salt tolerance of new Polish bread and durum wheat cultivars
}

\author{
Agnieszka Płażek • Maria Tatrzańska • Maciej Maciejewski • \\ Janusz Kościelniak • Krzysztof Gondek • Jarosław Bojarczuk • \\ Franciszek Dubert
}

Received: 8 January 2013/Revised: 17 April 2013/Accepted: 18 April 2013/Published online: 30 April 2013

(C) The Author(s) 2013. This article is published with open access at Springerlink.com

\begin{abstract}
In some regions of the world, low annual precipitation necessitates irrigation of crop plants which usually leads to soil salinity. Due to climatic changes this effect is also expected in the countries of Central Europe, and so in Poland. The aim of the study was (1) to compare tolerance to salt stress of Polish Triticum aestivum cvs. 'Bogatka' and 'Banderola' with T. durum cv. 'Komnata' and breeding line 121, and (2) to indicate the physiological parameter/parameters most suitable for such comparison. The investigation was performed in two experiments. In the first one, the germination ability of caryopses and coleoptiles' growth were estimated at $0-250 \mathrm{mM}$ of $\mathrm{NaCl}$. The second experiment was conducted on plants grown in a glasshouse in saline soil at $0-150 \mathrm{mM}$ of $\mathrm{NaCl}$ for 6 weeks. Salt tolerance was evaluated on the basis of following parameters: chlorophyll fluorescence, net
\end{abstract}

Communicated by W. Filek.

\footnotetext{
A. Płażek $(\square)$ J J. Kościelniak

Department of Plant Physiology, Faculty of Agriculture and Economics, University of Agriculture, Podłużna 3, 30-239 Kraków, Poland

e-mail: rrplazek@cyf-kr.edu.pl

M. Tatrzańska · M. Maciejewski · F. Dubert

F. Górski Institute of Plant Physiology, Polish Academy

of Sciences, Niezapominajek 21, 30-239 Kraków, Poland

K. Gondek

Department of Agricultural and Environmental Chemistry, Faculty of Agriculture and Economics, University of Agriculture, Mickiewicza 21, 31-120 Kraków, Poland

J. Bojarczuk

Plant Breeding Smolice, Plant Breeding and Acclimatization Institute Group, 63-740 Kobylin, Smolice 146, Poland
}

photosynthesis rate $\left(P_{\mathrm{N}}\right)$, transpiration rate $(E)$, stomatal conductance $\left(g_{\mathrm{s}}\right)$, cell membrane permeability (EL), proline content, fresh weight (FW), dry weight (DW), and relative water content (RWC). Highest germination of caryopses of durum cultivars was recorded at all the salinity levels; however, their coleoptiles were shorter than coleoptiles of bread wheat cultivars. Analysis of chlorophyll fluorescence showed that applied salt doses did not disturb the light phase of photosynthesis in all cultivars under study. Plants of durum wheat showed the higher dissipation of energy excess at the level of the antenna chlorophyll (DIo/CSm) under salinity as compared to plants of bread wheat. Both 'Komnata' and line 121 showed stronger $P_{\mathrm{N}}$ reduction as an effect of salinity. A decline of $P_{\mathrm{N}}$ was closely connected with a decrease in $g_{\mathrm{s}}$. The $P_{\mathrm{N}}$ correlated with a decrease in DW in all studied cultivars except 'Bogatka'. Control plants of 'Komnata' and line 121 were characterized by higher EL and proline level than bread wheat cultivars. An increasing cell membrane permeability correlated with a decrease of RWC in 'Banderola' and 'Komnata'. The content of proline under the increasing salinity correlated with changes of RWC in 'Banderola', 'Komnata' and line 121, which indicate protectoral role of proline against dehydration of tissue. Dry weight and RWC seem to be the parameters most useful in the salt-tolerance estimation of wheat plants. Taking into account the studied parameters 'Banderola' could be recognized as more salt tolerant, the degree of salinity tolerance of 'Bogatka' is the same as line 121, while 'Komnata' seems to be the most salt sensitive. The salt tolerance of T. aestivum and T. durum depends on the cultivar rather than the wheat species.

Keywords Chlorophyll fluorescence - Photosynthesis · Proline - Salt stress · Triticum aestivum - Triticum durum 


\section{Abbreviations}

ABS/CSm Light energy absorbed by leaf cross-section (CS)

DIo/CSm Dissipation of energy flux at the level of the antenna chlorophylls

$\begin{array}{ll}\text { DW } & \text { Dry weight } \\ E & \text { Transpiration rate } \\ \text { EL } & \text { Electrolyte leakage }\end{array}$

ETo/CSm Quantum yield of photosynthetic electron transport chain after $\mathrm{Q}_{\mathrm{A}}$ per cross-section (CS)

$F_{\mathrm{v}} / F_{\mathrm{m}} \quad$ Potential photochemical PSII efficiency

FW Fresh weight

$g_{\mathrm{s}} \quad$ Stomatal conductivity

OEC The fraction of $\mathrm{O}_{2}$ evolving centres PSII in comparison with the control sample

$\mathrm{PI}_{(\mathrm{CSm})}$ The performance index defined on a crosssection (CS) basis and calculated as: $\mathrm{PI}_{(\mathrm{ABS})} \times \mathrm{ABS} / \mathrm{CSm}$ where: $\mathrm{PI}_{(\mathrm{ABS})}-(\mathrm{RC} /$ $\mathrm{ABS}) \times\left(\varphi_{\mathrm{Po}} /\left(1-\varphi_{\mathrm{Po}}\right)\right) \times\left(\psi_{\mathrm{o}} /\left(1-\psi_{\mathrm{o}}\right)\right)$ $\mathrm{RC}$ is for reaction centre $\mathrm{ABS}$ is for absorption flux, $\varphi_{\mathrm{Po}}$ is for maximum quantum yield for primary photochemistry, and $\psi_{\mathrm{o}}$ is for the quantum yield for electron transport

$P_{\mathrm{N}} \quad$ Net photosynthesis rate

PSII Photosystem II

SSI Salt susceptibility index

QA The first stable electron quinone acceptor in PSII

TRo/CSm Trapped energy flux per cross-section (CS), quantum yield of primary photochemistry (from $\mathrm{RC}$ to $\mathrm{Q}_{\mathrm{A}}$ ) per $\mathrm{CS}$

RWC Relative water content

\section{Introduction}

The area affected by salinity in the world amounts to more than 800 million hectares of land, so salinity is becoming a serious problem for crop productivity (Munns and Tester 2008). Apart from natural soil salinity it is also evoked by such agronomic practices, such as improper irrigation and fertilization. In some regions of the world, low annual precipitation necessitates irrigation of crop plants with water which sometimes could not be completely desalted. However, in most cases soil salinity is an effect of salt accumulation over long cultivation periods and deforestation (Brini et al. 2009). In Poland, located in Central Europe, the progressive reduction of the groundwater level and more frequent periods of drought cause $30 \%$ losses of grain yield, which results in the need for plant watering
(Schar et al. 2004; Martyniak et al. 2007; Walter et al. 2011). It can, therefore, be expected that soil salinity will also affect regions that have not yet experienced such important problem with this environmental stress.

Salinity may cause osmotic stress and ion toxicity stress due to $\mathrm{Na}^{+}$and $\mathrm{Cl}^{-}$. Osmotic stress has an immediate effect on plant growth and stronger influence growth rates than ionic stress (Munns and Tester 2008). A high concentration of sodium ions disturbs the osmotic balance and results in physiological drought-inhibiting water uptake by the plant. The toxic influence of $\mathrm{Na}^{+}$may be manifested by the premature death of leaves, degradation of the cell membranes, inhibition of many enzymes, as well as damages of photosynthetic apparatus (Mitsuya et al. 2003). The biochemical strategies of plants within defence response to salinity are, among others: selective build-up or exclusion of salt ions, control uptake of ions by roots and transport into leaves, ion compartmentation, synthesis of osmolytes, changes in membrane structure, as well as activation of antioxidant defence system (Munns and Tester 2008). The threshold level of salt stress for most plants is approximately $40 \mathrm{mM} \mathrm{NaCl}$, which is equivalent to $4 \mathrm{dS} \mathrm{m}^{-1}$, while $50-100 \mathrm{mM} \mathrm{NaCl}$ is recognized as moderate salinity (Munns and James 2003). The latter authors maintain that only salinity over $200 \mathrm{mM}$ of $\mathrm{NaCl}$ identifies more salt tolerant genotypes of such plant species as wheat. However, Rawat et al. (2011) stated that $1.5 \mathrm{dS} \mathrm{m}^{-1}$ injures most plants. Most of the crops respond to salinity as typical glycophytes and demonstrate differentiated tolerance levels to this stress. According to Munns and Tester (2008), barley can be recognized as the most salt-tolerant cereal, while rice as the most sensitive one.

The most considerable criterion of salt tolerance is a production of biomass, which is significantly declined due to soil salinity. In cereals, the major effect of salinity is a reduction of the number of tillers (Munns and James 2003). According to Ashraf and Ali (2008), the selection of species sensitive to environmental stresses have been based on such parameters as relative growth and relative growth reduction. Reduced leaf development results in a build-up of unused photosynthate and may generate feedback signals to downregulate photosynthesis (Munns et al. 2000; Paul and Foyer 2001). Salt stress causes stomatal closure, which limits $\mathrm{CO}_{2}$ fixation. Lower rate of photosynthesis stimulates the generation of reactive oxygen species (ROS), which disturb the photochemical processes in thylakoids and can evoke strong photoinhibition (Sairam and Tyagi 2004).

The degree of salt and drought tolerance is often estimated on the basis of ion leakage (EL) from leaves as a parameter of cell membrane permeability (Munns and James 2003; Hura et al. 2007; Filek et al. 2012). These authors have stated that membrane permeability is affected 
by both osmotic and ion toxic stresses. Damage of membrane structure as a result of salinity can be due to toxic influence of $\mathrm{Na}^{+}$ions which cause strong membrane depolarization and the consequent effect of lipid peroxidation (Yasar et al. 2006).

Plant response to salinity is an accumulation of osmoprotectant proline. It provides membrane stability and alleviates cell membrane destruction caused by a high salt concentration. Moreover, proline may contribute to the osmotic regulation that maintains water content in leaves (Mansour 1998).

Bread wheat (Triticum aestivum L.) is the main cereal cultivated in Poland and in most countries around the world. Although cultivation of T. durum Desf. has not been yet popular in Poland, in recent years several new Polish spring and winter cultivars of this cereal have been bred. Triticum durum is the second most important wheat in Southern Europe and the Middle East. In addition, it is often cultivated on soils affected by salinity although, according to some reports, durum wheat is less salt tolerant compared to bread wheat (Noori and McNeilly 2000; Munns and James 2003). Greenway and Munns (1980) have stated that the growth and photosynthetic efficiency in wheat may be reduced by salinity even at a low salt concentration. Munns and James (2003) maintain additionally that the plant resistance degree to salinity depends on stress duration, so screening of plant resistance to salt should last at least 2-3 weeks.

The aim of the presented work was to evaluate if new Polish cultivars of $T$. durum are less tolerant to salinity than cultivars of $T$. aestivum. The response of plants of both wheat species to salinity was estimated on the basis of the parameters most often described in the literature. The study was performed on germinating caryopses at $0-250 \mathrm{mM}$ $\mathrm{NaCl}$ level and plants grown at $0-150 \mathrm{mM} \mathrm{NaCl}$. The caryopses germination ability in different salt concentrations, chlorophyll fluorescence, photosynthesis and transpiration rate, stomatal conductance, ion leakage from leaves, proline content, as well as fresh and dry weight of plants grown under salt stress were evaluated. On the basis of results obtained in two independent experiments performed in the controlled conditions, the parameters most useful in the screening of plant salt tolerance were chosen.

\section{Materials and methods}

Plant material

The study was performed on T. aestivum winter cultivars 'Bogatka' and 'Banderola', and T. durum winter cultivar 'Komnata' and line 121. Caryopses of T. aestivum were obtained from the Department of Cereal Plants of the Plant
Breeding and Acclimatization Institute in Kraków (Poland), while T. durum from Plant Breeding Smolice, Plant Breeding and Acclimatization Institute Group (Poland).

Germination of caryopses and coleoptiles length

Caryopses were sterilized in $0.5 \% \mathrm{NaOCl}$ for $15 \mathrm{~min}$, then washed three times with sterile distilled water and placed on Petri dishes $(\varnothing=10 \mathrm{~cm})$ with filter paper wetted with $\mathrm{NaCl}$ solutions of the following concentrations: 0 (control), 20, 40, 70, 100, 150, 200, and $250 \mathrm{mM}$. Fifteen caryopses were put on each dish. The evaluation was conducted in five replicates (five dishes for each salt concentration). Caryopses were germinated in the dark at $25{ }^{\circ} \mathrm{C}$ for 6 days. After this time, a percentage of germinated caryopses was calculated for each dish, while the length of coleoptiles was measured individually for 20 seedlings grown at each salt treatment. The influence of salinity was expressed as salt susceptibility index (SSI) calculated as below:

$\mathrm{SSI}=\left(1-G_{1} / G_{2}\right) \times 100$, where: $G_{1}$ grain germination in salt solution, $G_{2}$ grain germination in pure water (control). Analogically, SSI for coleoptiles length was calculated. The presented results are the means of two independent experiments.

\section{Plant cultivation and salt treatments}

Pots $\left(4 \mathrm{dm}^{3}\right)$ were filled with commercial substrate $(\mathrm{pH} 6)$ and watered with solutions of the following $\mathrm{NaCl}$ concentrations: 0 (control), 20, 40, 70, 100, 125, and $150 \mathrm{mM}$. The applied salt concentrations were chosen on the basis of results relating to germination ability of seeds, obtained in the first stage of the investigation. To state the real salt content in the soil, the conductivity of soil solution was estimated for each $\mathrm{NaCl}$ treatment. Soil was air-dried at $70{ }^{\circ} \mathrm{C}$ for 2 days, mixed with the water in a ratio of $1: 5$ and conductivity of the soil solution was analyzed using a conductometer (CI 317, Elmetron, Poland). The results of the conductivity test for studied $\mathrm{NaCl}$ concentration are presented in Table 1.

Table 1 Conductivity of commercial soil watered with $\mathrm{NaCl}$ solutions of $0,20,40,70,100,125$, and $150 \mathrm{mM}$

\begin{tabular}{lc}
\hline $\mathrm{NaCl}(\mathrm{mM})$ & $\mathrm{dS} \mathrm{m} \mathrm{s}^{-1}$ \\
\hline 0 & 1.695 \\
20 & 2.675 \\
40 & 5.005 \\
70 & 8.365 \\
100 & 11.250 \\
125 & 13.750 \\
150 & 17.200 \\
\hline
\end{tabular}


Seeds, sterilized as described above, were sown in pots and nine plants per pot were maintained. The plants were grown for 6 weeks under glasshouse conditions at $22{ }^{\circ} \mathrm{C}$, in daylight (April-May) supplemented with the light of $400 \mu \mathrm{mol} \mathrm{m}{ }^{-2} \mathrm{~s}^{-2}$ PPFD (AGRO Philips sodium lamps) up to a 16-h photoperiod. The plants were watered with $\mathrm{NaCl}$ solutions of the same volume, and once a week with Hoagland's medium (Hoagland and Arnon 1938) was added to the salt solutions to obtain $\mathrm{NaCl}$ concentration as above. The described plant growth conditions were the same in two independent experiments. All analyses were performed after a 6-week cultivation of plants under salt stress. Similarly as in the case of evaluation of seed germination capacity, the presented results are the means of both experiments.

\section{Chlorophyll fluorescence}

Chlorophyll fluorescence was measured in the third upper well-developed leaf using the Plant Efficiency Analyser (PEA) (Hansatech Ltd., Kings Lynn, UK). Before measurements, the LED-light source of the fluorometer was calibrated using an SQS light meter (Hansatech Ltd., Kings Lynn, UK). The excitation irradiance had an intensity of $3,000 \mu \mathrm{mol} \mathrm{m} \mathrm{m}^{-2} \mathrm{~s}^{-2}$ (peak at $650 \mathrm{~nm}$ ). Measurements were taken after $30 \mathrm{~min}$ of leaf adaptation to darkness (clips with a 4-mm diameter hole). Fluorescence intensity was measured with a PIN-photodiode after being passed through a long-pass filter. Changes in fluorescence were registered during irradiation between $10 \mu$ s and $1 \mathrm{~s}$. During the initial $2 \mathrm{~ms}$, the data were collected every $10 \mu$ s with 12-bit resolution. After this period, the frequency of measurements was reduced automatically. On the basis of these measurements, the following parameters (per excited leaf cross-section, CS) were calculated based on the theory of energy flow in PSII and using the JIP test as has been described elsewhere (Lazár 1999; Strasser et al. 2000): $\mathrm{ABS} / \mathrm{CSm}, \mathrm{TRo} / \mathrm{CSm}, \mathrm{ETo} / \mathrm{CSm}, \mathrm{DIo} / \mathrm{CSm}, \mathrm{PI}_{(\mathrm{CSm})}, \mathrm{OEC}$, $F_{\mathrm{v}} / F_{\mathrm{m}}$. The measurements were performed in 15 replicates.

\section{Gas exchange}

Net photosynthetic $\left(P_{\mathrm{N}}\right)$, transpiration $(E)$ rates and stomatal conductance $\left(g_{\mathrm{s}}\right)$ of plants in the stage of the fifth leaf were measured by means of an infrared gas analyzer (Ciras-1, Hansatech Ltd., Kings Lynn, UK) with a Parkinson leaf chamber (PLCO) automatically controlling the measurement conditions. The irradiation system consisted of halogen lamps. The leaf chamber was fastened on the middle part of the fourth leaf. The flow rate of air with constant $\mathrm{CO}_{2}$ concentration $\left[400 \mu \mathrm{mol}\left(\mathrm{CO}_{2}\right) \mathrm{mol}^{-1}\right.$ (air)] through the assimilation chamber was $300 \mathrm{~cm}^{-3} \mathrm{~min}^{-1}$. The temperature of the leaves was $25^{\circ} \mathrm{C}$, the air humidity
$40 \%$, and the irradiance $800 \mu \mathrm{mol}\left(\right.$ photon) $\mathrm{m}^{-2} \mathrm{~s}^{-1}$. The measurements were performed in 15 replicates.

Electrolyte leakage

Ion leakage determining the plasma membrane's integrity was measured in the fourth upper, well-expanded leaves. Leaf discs $(\varnothing=1 \mathrm{~cm})$ were washed in distilled water, put into plastic vials containing $10 \mathrm{~cm}^{3}$ deionised water and shaken for $24 \mathrm{~h}(50 \mathrm{rpm})$ at $20^{\circ} \mathrm{C}$. Next, ion conductivity was measured $\left(\mathrm{EL}_{1}\right)$ using a conductometer (CI 317, Elmetron, Poland). Then the samples were frozen at $-40{ }^{\circ} \mathrm{C}$ for $24 \mathrm{~h}$ after thawing they were shaken again for $24 \mathrm{~h}$ and, next, total ion leakage $\left(\mathrm{EL}_{2}\right)$ was measured. Membrane permeability was expressed as a percentage of total electrolyte leakage $\left(\mathrm{EL}_{1} \times 100 / \mathrm{EL}_{2}\right)$. The measurements were done in ten replicates for each $\mathrm{NaCl}$ treatment.

\section{Proline content}

The content of free proline in wheat leaves was determined as described by Bates et al. (1973). Samples were homogenized in $3 \%(\mathrm{w} / \mathrm{v})$ sulfosalicylic acid to precipitate protein, and centrifuged at $14,000 \times g$ for $10 \mathrm{~min}$. The reaction mixture contained $2 \mathrm{~cm}^{3}$ glacial acetic acid, $2 \mathrm{~cm}^{3}$ ninhydrin reagent $(2.50 \% \mathrm{w} / \mathrm{v}$ ninhydrin in $60 \%$ v/v $6 \mathrm{M}$ phosphoric acid) and $2 \mathrm{~cm}^{3}$ of supernatant. The incubation lasted for $1 \mathrm{~h}$ at $90{ }^{\circ} \mathrm{C}$ then, after stopping the reaction with ice, $4 \mathrm{~cm}^{3}$ of toluene was added and mixed by vortex. The upper toluene phase was decanted into a glass cuvette and absorbance was measured at $\lambda=520 \mathrm{~nm}$. The concentration was assayed using proline as the calibration standard. Each assay was performed in seven replicates representing seven leaves from different plants for each treatment. The content of proline was expressed as $\mathrm{mg} \mathrm{g}^{-1}$ of DW.

Fresh and dry weight and relative water content

Fresh weight (FW) of the above ground part of the plants was weighed, next their dry weight (DW) was estimated after 48 -h drying at $70{ }^{\circ} \mathrm{C}$. RWC in leaves was calculated according to the formula: (FW - DW)/DW. The RWC parameter means number of grams of water needed to hydrate $1 \mathrm{~g}$ of plant dry weigh. Analyses were done in 15 replicates.

Statistical analyses

All data were analyzed with Statistica 9.0 software (Statsoft, Tulsa, OK, USA) using a one-way ANOVA. The differences between means were analyzed according to multiple range Duncan's test at $p<0.05$. 


\section{Results}

\section{Germination of caryopses}

The percentage of germinated grains of 'Bogatka' was similar in $\mathrm{NaCl}$ concentrations of $0-150 \mathrm{mM}$, only higher salt levels (200 and $250 \mathrm{mM}$ of $\mathrm{NaCl}$ ) significantly decreased its caryopses germination ability (Table 2). In 'Banderola', a significant reduction of germination was noted already at $20 \mathrm{mM}$ of $\mathrm{NaCl}$. This cultivar was also characterized by the highest salt susceptibility amongst all the studied cultivars (SSI at $250 \mathrm{mM}$ of $\mathrm{NaCl}$ amounted to 33.6, 16.2, 2.2, and $0.7 \%$ for 'Banderola', 'Bogatka', line 121 and 'Komnata', respectively). Both cultivars of durum wheat demonstrated non-significant salinity influence on the number of germinated grains.

Salt stress affected stronger coleoptiles' growth than seed germination (Table 3). In control combination coleoptiles of durum wheat were shorter as compared to coleoptiles of bread wheat. 'Bogatka' showed considerable reduction of its coleoptiles' length already at $20-\mathrm{mM}$ concentration, while 'Banderola' at $70 \mathrm{mM}$ and higher. The pattern of salt influence on coleoptiles' length noted for 'Banderola' was similar as in both durum cultivars. The values of SSI showed that the coleoptiles of both bread wheat cultivars were less sensitive to salinity than the durum wheat ones: SSI for 'Bogatka' and 'Banderola' at $250 \mathrm{mM}$ amounted to 84.3 and $83.7 \%$, respectively, while for line 121 and 'Komnata' it amounted to 87.9 and $89.3 \%$, respectively.

\section{Chlorophyll fluorescence}

Analysis of chlorophyll fluorescence clearly divided the plant response to salt stress into two groups: bread wheat

Table 2 Germination of caryopses of T. aestivum and T. durum cultivars treated with salt solutions of concentrations in the range of $0-250 \mathrm{mM}$

\begin{tabular}{|c|c|c|c|c|c|c|c|c|}
\hline \multirow{3}{*}{$\begin{array}{l}\mathrm{NaCl} \\
(\mathrm{mM})\end{array}$} & \multicolumn{4}{|c|}{ T. aestivum } & \multicolumn{4}{|c|}{ T. durum } \\
\hline & \multicolumn{2}{|c|}{ Bogatka } & \multicolumn{2}{|c|}{ Banderola } & \multicolumn{2}{|c|}{ Komnata } & \multicolumn{2}{|c|}{ Line 121} \\
\hline & $\%$ & SSI & $\%$ & SSI & $\%$ & SSI & $\%$ & $\mathrm{SS}$ \\
\hline 0 & $94.5 \mathrm{a}$ & 0 & $100 \mathrm{a}$ & 0 & $97.2 \mathrm{a}$ & 0 & $97.6 a$ & 0 \\
\hline 20 & $91.8 \mathrm{a}$ & 2.9 & $94.0 \mathrm{~b}$ & 6.0 & $97.2 \mathrm{a}$ & 0 & $96.6 a$ & 2.0 \\
\hline 40 & $94.5 \mathrm{a}$ & 0 & $94.0 \mathrm{~b}$ & 6.0 & $97.2 \mathrm{a}$ & 0 & $97.7 \mathrm{a}$ & 0 \\
\hline 70 & $94.5 \mathrm{a}$ & 0 & $94.0 \mathrm{~b}$ & 6.0 & $97.2 \mathrm{a}$ & 0 & $93.3 \mathrm{a}$ & 4.4 \\
\hline 100 & $91.8 \mathrm{a}$ & 2.9 & $91.9 \mathrm{~b}$ & 8.1 & $90.6 \mathrm{a}$ & 6.8 & $96.1 \mathrm{a}$ & 1.5 \\
\hline 150 & $84.6 \mathrm{ab}$ & 10.5 & $79.1 b c$ & 20.9 & $97.1 \mathrm{a}$ & 0.1 & $96.7 \mathrm{a}$ & 1.0 \\
\hline 200 & $81.1 \mathrm{~b}$ & 14.2 & $72.6 \mathrm{c}$ & 27.4 & $95.8 \mathrm{a}$ & 0.9 & $97.6 \mathrm{a}$ & 0 \\
\hline 250 & $79.2 \mathrm{~b}$ & 16.2 & $66.4 \mathrm{c}$ & 33.6 & $96.5 \mathrm{a}$ & 0.7 & $95.5 \mathrm{a}$ & 2.2 \\
\hline
\end{tabular}

Left column: percentage of germinating grains, right column: values of SSI coefficient $(\%)$. Means $(n=5)$ within each column marked with the same letters do not differ statistically according to multiple range Duncan's test $(p<0.05)$
Table 3 Length of the coleoptiles of $T$. aestivum and T. durum cultivars germinating in salt solutions of concentrations in the range of $0-250 \mathrm{mM}$

\begin{tabular}{|c|c|c|c|c|c|c|c|c|}
\hline \multirow{3}{*}{$\begin{array}{l}\mathrm{NaCl} \\
(\mathrm{mM})\end{array}$} & \multicolumn{4}{|c|}{ T. aestivum } & \multicolumn{4}{|c|}{ T. durum } \\
\hline & \multicolumn{2}{|c|}{ Bogatka } & \multicolumn{2}{|c|}{ Banderola } & \multicolumn{2}{|c|}{ Komnata } & \multicolumn{2}{|c|}{ Line 121} \\
\hline & $\mathrm{mm}$ & SSI & $\mathrm{mm}$ & SSI & $\mathrm{mm}$ & SSI & $\mathrm{mm}$ & SSI \\
\hline 0 & $61.0 \mathrm{a}$ & 0 & $64.3 \mathrm{a}$ & 0 & $55.1 \mathrm{a}$ & 0 & $48.6 \mathrm{a}$ & 0 \\
\hline 20 & $47.7 b$ & 21.8 & $63.4 \mathrm{a}$ & 1.4 & $49.2 \mathrm{a}$ & 10.7 & $46.6 \mathrm{a}$ & 4.1 \\
\hline 40 & $34.5 \mathrm{c}$ & 43.4 & $60.5 \mathrm{a}$ & 5.9 & $48.2 \mathrm{a}$ & 12.5 & $42.4 \mathrm{a}$ & 12.8 \\
\hline 70 & $27.2 \mathrm{~cd}$ & 55.4 & $40.3 b$ & 37.3 & $26.9 b$ & 51.2 & $28.7 b$ & 40.9 \\
\hline 100 & $23.5 \mathrm{~d}$ & 61.5 & $27.7 \mathrm{c}$ & 56.9 & $23.6 b$ & 57.2 & $26.6 \mathrm{~b}$ & 45.3 \\
\hline 150 & $23.0 \mathrm{~d}$ & 62.3 & $25.9 \mathrm{c}$ & 59.7 & $18.0 \mathrm{bc}$ & 67.3 & $15.1 \mathrm{c}$ & 68.9 \\
\hline 200 & $18.0 \mathrm{de}$ & 70.5 & $23.5 \mathrm{c}$ & 63.5 & $9.6 \mathrm{c}$ & 82.6 & $10.4 \mathrm{c}$ & 78.4 \\
\hline 250 & $9.6 \mathrm{e}$ & 84.3 & $10.5 \mathrm{~d}$ & 83.7 & $5.9 \mathrm{c}$ & 89.3 & $5.9 \mathrm{~d}$ & 87.9 \\
\hline
\end{tabular}

Left column: length of the coleoptiles $(\mathrm{mm}) 6$ days after germination, right column: values of SSI coefficient $(\%)$. Means $(n=20)$ marked within each column with the same letters do not differ statistically according to multiple range Duncan's test $(p<0.05)$

and durum wheat cultivars. In the case of 'Bogatka', most studied parameters reached the highest values in $\mathrm{NaCl}$ concentration of 40 and $70 \mathrm{mM}$ (Table 4). Salt concentration of $100-150 \mathrm{mM}$ decreased the values of such parameters as ABS/CSm, TRo/CSm, ETo/CSm and DIo/ CSm, while $F_{\mathrm{v}} / F_{\mathrm{m}}$ and $\mathrm{PI}_{\mathrm{CSm}}$ reached the highest level in plants grown at $150 \mathrm{mM}$. Efficiency of OEC did not change under rising salinity. 'Banderola' also showed the highest efficiency of photosynthetic apparatus at $70 \mathrm{mM}$ of $\mathrm{NaCl}$. Only $F_{\mathrm{v}} / F_{\mathrm{m}}$ reached the highest level at $150 \mathrm{mM}$, while the OEC parameter-similarly as in 'Bogatka' —was generally not sensitive to salt stress. Likewise as in 'Bogatka', DIo/CSm (energy dissipation) reached the maximal values at $70 \mathrm{mM}$, while a higher salt concentration caused its decrease.

Both cultivars of $T$. durum demonstrated the highest efficiency of photosynthetic apparatus in plants grown at 125 and $150 \mathrm{mM}$ of $\mathrm{NaCl}$. In the case of 'Komnata', OEC reached the highest values in plants grown at 40 and $100 \mathrm{mM}$, while in line 121 it increased at $40 \mathrm{mM}$ and at higher salt levels. Potential photochemical efficiency $\left(F_{\mathrm{v}} / F_{\mathrm{m}}\right)$ did not change in 'Komnata', while it increased gradually in higher salt concentrations. In both durum cultivars DIo/CSm was maximal at the highest salt concentration.

\section{Gas exchange}

All the studied cultivars, with the exception of 'Bogatka', showed a decrease in $P_{\mathrm{N}}$ under rising soil salinity (Table 5). 'Bogatka' reached the highest $P_{\mathrm{N}}$ rate at $125 \mathrm{mM}$ of $\mathrm{NaCl}$, while at $150 \mathrm{mM}$ it declined up to the 
Table 4 Chlorophyll fluorescence parameters of T. aestivum and T. durum cultivars grown in soil treated with salt solutions of concentrations in the range of $0-150 \mathrm{mM}$

\begin{tabular}{|c|c|c|c|c|c|c|c|}
\hline & \multicolumn{7}{|c|}{$\mathrm{NaCl}(\mathrm{mM})$} \\
\hline & 0 & 20 & 40 & 70 & 100 & 125 & 150 \\
\hline \multicolumn{8}{|l|}{ T. aestivum } \\
\hline \multicolumn{8}{|l|}{ Bogatka } \\
\hline $\mathrm{ABS} / \mathrm{CSm}$ & $35,003 b$ & $37,845 b$ & $40,643 a$ & $41,375 a$ & $36,950 \mathrm{~b}$ & $35,048 b$ & $36,653 b$ \\
\hline TRo/CSm & $27,616 \mathrm{c}$ & $30,051 \mathrm{ab}$ & $32,298 \mathrm{a}$ & $32,253 \mathrm{a}$ & $29,233 b$ & $27,768 \mathrm{c}$ & $29,428 b$ \\
\hline $\mathrm{ETo} / \mathrm{CSm}$ & $15,047 \mathrm{c}$ & $16,483 b$ & $17,667 \mathrm{a}$ & $17,840 \mathrm{a}$ & $16,306 b$ & $15,524 \mathrm{c}$ & $16,698 b$ \\
\hline $\mathrm{DIo} / \mathrm{CSm}$ & $7,387 \mathrm{c}$ & $7,793 \mathrm{c}$ & $8,345 b$ & $9,122 \mathrm{a}$ & $7,716 \mathrm{c}$ & $7,280 \mathrm{c}$ & $7,224 \mathrm{c}$ \\
\hline $\mathrm{PI}_{(\mathrm{CSm})}$ & $61,5178 \mathrm{c}$ & $676,708 b$ & $728,863 \mathrm{a}$ & $692,419 a b$ & $676,997 b$ & $637,052 \mathrm{c}$ & $770,766 \mathrm{a}$ \\
\hline OEC & $0.4325 \mathrm{a}$ & $0.4466 \mathrm{a}$ & $0.4548 \mathrm{a}$ & $0.4455 \mathrm{a}$ & $0.4384 \mathrm{a}$ & $0.4764 \mathrm{a}$ & $0.4890 \mathrm{a}$ \\
\hline$F_{\mathrm{v}} / F_{\mathrm{m}}$ & $0.833 b$ & $0.839 \mathrm{~b}$ & $0.840 \mathrm{ab}$ & $0.823 \mathrm{c}$ & $0.835 \mathrm{~b}$ & $0.838 b$ & $0.846 a$ \\
\hline \multicolumn{8}{|l|}{ Banderola } \\
\hline $\mathrm{ABS} / \mathrm{CSm}$ & $24,078 \mathrm{~d}$ & $27,921 \mathrm{c}$ & $29,345 b$ & $33,932 \mathrm{a}$ & $25,409 \mathrm{~cd}$ & $26,239 \mathrm{c}$ & $29,917 b$ \\
\hline $\mathrm{TRo} / \mathrm{CSm}$ & $19,089 \mathrm{~d}$ & $223,59 b c$ & $23,473 b c$ & $27,030 \mathrm{a}$ & $20,328 \mathrm{c}$ & $20,920 \mathrm{c}$ & $24074 b$ \\
\hline $\mathrm{ETo} / \mathrm{CSm}$ & $10,517 \mathrm{~d}$ & $12,638 b$ & $12,881 b$ & $15,661 \mathrm{a}$ & $11,428 \mathrm{c}$ & $11,881 \mathrm{c}$ & $13,625 b$ \\
\hline DIo/CSm & $4,988 \mathrm{c}$ & $5,562 \mathrm{bc}$ & $5,871 \mathrm{~b}$ & $6,901 \mathrm{a}$ & $5,080 \mathrm{c}$ & $5,318 \mathrm{bc}$ & $5,843 \mathrm{~b}$ \\
\hline $\mathrm{PI}_{(\mathrm{CSm})}$ & $431,991 \mathrm{~d}$ & $576,892 \mathrm{c}$ & $557,714 \mathrm{c}$ & $709,867 \mathrm{a}$ & $510,813 \mathrm{c}$ & $545,928 \mathrm{c}$ & $63,7240 \mathrm{~b}$ \\
\hline OEC & $0.4766 \mathrm{ab}$ & $0.4979 \mathrm{ab}$ & $0.4615 b$ & $0.5151 \mathrm{ab}$ & $0.4816 \mathrm{ab}$ & $0.5374 a$ & $0.5253 \mathrm{ab}$ \\
\hline$F_{\mathrm{v}} / F_{\mathrm{m}}$ & $0.838 b$ & $0.843 \mathrm{ab}$ & $0.845 \mathrm{a}$ & $0.836 \mathrm{~b}$ & $0.843 \mathrm{ab}$ & $0.839 \mathrm{~b}$ & $0.847 \mathrm{a}$ \\
\hline \multicolumn{8}{|l|}{ T. durum } \\
\hline \multicolumn{8}{|l|}{ Komnata } \\
\hline $\mathrm{ABS} / \mathrm{CSm}$ & $40,258 d$ & $42,312 b$ & $42,304 b$ & $41,562 \mathrm{c}$ & $41,556 \mathrm{c}$ & $41,304 c$ & $44,143 \mathrm{a}$ \\
\hline TRo/CSm & $31,449 \mathrm{~d}$ & $33,423 b$ & $33,504 b$ & $32,758 \mathrm{c}$ & $33,029 b$ & $32,534 \mathrm{c}$ & $35,106 \mathrm{a}$ \\
\hline $\mathrm{ETo} / \mathrm{CSm}$ & $1,6479 d$ & $1,8570 \mathrm{c}$ & $19,007 \mathrm{~b}$ & $18,425 \mathrm{c}$ & $18,499 \mathrm{c}$ & $18,068 \mathrm{c}$ & $19,924 \mathrm{a}$ \\
\hline $\mathrm{DIo} / \mathrm{CSm}$ & $8,809 b$ & $8,889 b$ & $8,800 \mathrm{~b}$ & $8,803 b$ & $8,526 \mathrm{c}$ & $8,770 \mathrm{~b}$ & $9,037 \mathrm{a}$ \\
\hline $\mathrm{PI}_{(\mathrm{CSm})}$ & $599,760 d$ & $72,9270 \mathrm{c}$ & $827,867 b$ & $769,277 \mathrm{c}$ & $841,910 \mathrm{~b}$ & $753,967 \mathrm{c}$ & $911,118 \mathrm{a}$ \\
\hline OEC & $0.4185 \mathrm{c}$ & $0.4506 \mathrm{~b}$ & $0.4846 a$ & $0.4479 b$ & $0.4982 \mathrm{a}$ & $0.4367 b$ & $0.4367 b$ \\
\hline$F_{\mathrm{v}} / F_{\mathrm{m}}$ & $0.827 b$ & $0.836 \mathrm{a}$ & $0.835 \mathrm{a}$ & $0.831 \mathrm{a}$ & $0.836 \mathrm{a}$ & $0.823 a$ & $0.836 a$ \\
\hline \multicolumn{8}{|l|}{ Line 121} \\
\hline $\mathrm{ABS} / \mathrm{CSm}$ & $24,971 \mathrm{e}$ & $24,542 \mathrm{e}$ & $25,798 d$ & $26,832 \mathrm{c}$ & $26,175 \mathrm{c}$ & $27,403 b$ & $28,566 \mathrm{a}$ \\
\hline TRo/CSm & $19,895 \mathrm{bc}$ & $19,207 \mathrm{c}$ & $20,458 b$ & $21,252 \mathrm{ab}$ & $20,861 b$ & $22,001 \mathrm{a}$ & $22,136 a$ \\
\hline $\mathrm{ETo} / \mathrm{CSm}$ & $10,641 \mathrm{c}$ & $10,983 \mathrm{c}$ & $12,079 b$ & $12,462 b$ & $12,249 b$ & $12,742 \mathrm{a}$ & $12,850 \mathrm{a}$ \\
\hline DIo/CSm & $5,075 \mathrm{c}$ & $5,334 \mathrm{~b}$ & $5,339 \mathrm{~b}$ & $5,579 \mathrm{~b}$ & $5,313 b$ & $5,402 \mathrm{~b}$ & $6,430 \mathrm{a}$ \\
\hline $\mathrm{PI}_{(\mathrm{CSm})}$ & $413,166 \mathrm{c}$ & $420,727 \mathrm{c}$ & $50,9048 b$ & $501763 b$ & $537,695 \mathrm{ab}$ & $579,274 \mathrm{a}$ & $59,400 \mathrm{a}$ \\
\hline OEC & $0.4024 \mathrm{c}$ & $0.4843 b$ & $0.5411 \mathrm{a}$ & $0.5123 \mathrm{ab}$ & $0.4985 \mathrm{ab}$ & $0.4982 \mathrm{ab}$ & $0.4984 \mathrm{ab}$ \\
\hline$F_{\mathrm{v}} / F_{\mathrm{m}}$ & $0.828 \mathrm{c}$ & $0.828 \mathrm{c}$ & $0.837 b$ & $0.840 \mathrm{~b}$ & $0.841 \mathrm{ab}$ & $0.847 \mathrm{a}$ & $0.851 \mathrm{a}$ \\
\hline
\end{tabular}

Means $(n=15)$ for each parameter marked with the same letters do not differ statistically according to multiple range Duncan's test $(p<0.05)$

control level. 'Banderola' showed a significant decrease in $P_{\mathrm{N}}$ at $40 \mathrm{mM}$, while in both durum cultivars at $20 \mathrm{mM}$. However, at $\mathrm{NaCl}$ concentration above $40 \mathrm{mM}$ no changes in $P_{\mathrm{N}}$ in line 121 were shown, while in 'Komnata' the considerable decrease of this parameter was observed. Finally at $150-\mathrm{mM} \mathrm{NaCl}$ concentration, the decline of $P_{\mathrm{N}}$ amounted to $26 \%$ in 'Komnata' and line 121, and to 4 and $24 \%$ in 'Bogatka' and 'Banderola', respectively. The transpiration rate $(E)$ in 'Bogatka' declined by $27 \%$ only at $150 \mathrm{mM}$, while in both 'Banderola' and line 121 it decreased already at $40 \mathrm{mM}$, and finally at $150 \mathrm{mM}$ was reduced by $43 \%$. Transpiration efficiency and stomatal conductivity in 'Komnata' plants was limited already at $20 \mathrm{mM}$ and proceeded in higher salt concentrations, reaching at $150 \mathrm{mM}$ of $\mathrm{NaCl}$ a $50 \%$ lower level compared to the control. In 'Bogatka', $g_{\mathrm{s}}$ decreased under increasing salinity; however, the significant limitation of this parameter was observed only at $150 \mathrm{mM}$. Taking into account the reduction of gas exchange parameters, 'Bogatka' demonstrated the lowest sensitivity to salinity among the studied cultivars of both wheat species. However, it is necessary to underline that, even at highest salt concentration, the $P_{\mathrm{N}}$ 
Table 5 Net photosynthesis rate $\left(\mu \mathrm{mol} \mathrm{CO} \mathrm{CO}_{2} \mathrm{~m}^{-2} \mathrm{~s}^{-1}\right.$ ), transpiration efficiency $\left(\mathrm{mmol} \mathrm{H}_{2} \mathrm{O} \mathrm{m}^{-2} \mathrm{~s}^{-1}\right.$ ), and stomatal conductance (mmol $\mathrm{H}_{2} \mathrm{O} \mathrm{m}^{-2} \mathrm{~s}^{-1}$ ) of seedlings of T. aestivum and T. durum cultivars grown in soil treated with salt solutions of concentrations in the range of $0-150 \mathrm{mM}$

\begin{tabular}{|c|c|c|c|c|c|c|c|c|c|c|c|c|}
\hline \multirow[t]{3}{*}{$\mathrm{NaCl}(\mathrm{mM})$} & \multicolumn{6}{|c|}{ T. aestivum } & \multicolumn{6}{|c|}{ T. durum } \\
\hline & \multicolumn{3}{|c|}{ Bogatka } & \multicolumn{3}{|c|}{ Banderola } & \multicolumn{3}{|c|}{ Komnata } & \multicolumn{3}{|c|}{ Line 121} \\
\hline & $P_{\mathrm{N}}$ & $E$ & $g_{\mathrm{s}}$ & $P_{\mathrm{N}}$ & $E$ & $g_{\mathrm{s}}$ & $P_{\mathrm{N}}$ & $E$ & $g_{\mathrm{s}}$ & $P_{\mathrm{N}}$ & $E$ & $g_{\mathrm{s}}$ \\
\hline 0 & $11.3 \mathrm{~cd}$ & $2.2 \mathrm{ab}$ & $77 \mathrm{ab}$ & $11.4 \mathrm{a}$ & $2.1 \mathrm{a}$ & $77 \mathrm{a}$ & $13.5 \mathrm{a}$ & $2.8 \mathrm{a}$ & $107 a$ & $14.3 .0 \mathrm{a}$ & $2.8 \mathrm{a}$ & $120 \mathrm{a}$ \\
\hline 20 & $11.7 \mathrm{bc}$ & $2.1 \mathrm{ab}$ & $77 \mathrm{ab}$ & $11.6 \mathrm{a}$ & $2.0 \mathrm{a}$ & $75 a$ & $12.9 \mathrm{~b}$ & $2.3 b$ & $89 b$ & $13.0 \mathrm{~b}$ & $2.6 \mathrm{a}$ & $105 a$ \\
\hline 40 & $11.8 \mathrm{bc}$ & $2.0 \mathrm{ab}$ & $75 \mathrm{ab}$ & $9.8 \mathrm{~b}$ & $1.6 \mathrm{~b}$ & $60 \mathrm{~b}$ & $13.0 \mathrm{ab}$ & $2.2 \mathrm{c}$ & $84 b$ & $10.9 \mathrm{c}$ & $2.0 \mathrm{~b}$ & $88 \mathrm{~b}$ \\
\hline 70 & $11.4 \mathrm{c}$ & $1.9 \mathrm{~b}$ & $68 b$ & $8.6 \mathrm{~d}$ & $1.3 \mathrm{~cd}$ & $46 \mathrm{~cd}$ & $11.8 \mathrm{c}$ & $1.6 \mathrm{~d}$ & $60 \mathrm{c}$ & $10.5 \mathrm{c}$ & $1.6 \mathrm{~cd}$ & $61 \mathrm{c}$ \\
\hline 100 & $12.2 \mathrm{~b}$ & $2.2 \mathrm{a}$ & $82 a$ & $8.2 \mathrm{~d}$ & $1.2 \mathrm{~d}$ & $42 d$ & $8.3 \mathrm{f}$ & $1.2 \mathrm{f}$ & $42 \mathrm{e}$ & $11.1 \mathrm{c}$ & $1.8 \mathrm{bc}$ & $70 \mathrm{c}$ \\
\hline 125 & $13.3 \mathrm{a}$ & $2.0 \mathrm{ab}$ & $76 a b$ & $9.4 \mathrm{bc}$ & $1.4 \mathrm{c}$ & $49 \mathrm{c}$ & $10.8 \mathrm{~d}$ & $1.4 \mathrm{e}$ & $52 \mathrm{~d}$ & $10.7 \mathrm{c}$ & $1.5 \mathrm{~d}$ & $58 \mathrm{c}$ \\
\hline 150 & $10.9 \mathrm{~d}$ & $1.4 \mathrm{c}$ & $52 \mathrm{c}$ & $8.7 \mathrm{~cd}$ & $1.2 \mathrm{~d}$ & $44 \mathrm{~cd}$ & $10.01 \mathrm{e}$ & $1.4 \mathrm{e}$ & $51 \mathrm{~d}$ & $10.5 \mathrm{c}$ & $1.6 \mathrm{~d}$ & $56 \mathrm{c}$ \\
\hline
\end{tabular}

Means $(n=15)$ within each column marked with the same letters do not differ statistically according to multiple range Duncan's test $(p<0.05)$ $P_{N}$ net photosynthesis rate, $E$ transpiration efficiency, $g_{s}$ stomatal conductance

Table 6 Percentage of electrolyte leakage from leaf cells of T. aestivum and T. durum cultivars grown in soil treated with salt solutions of concentrations in the range of $0-150 \mathrm{mM}$

\begin{tabular}{llllll}
\hline $\mathrm{NaCl}(\mathrm{mM})$ & \multicolumn{2}{l}{ T. aestivum } & & \multicolumn{2}{l}{ T. durum } \\
\cline { 2 - 3 } \cline { 6 - 6 } \cline { 5 - 6 } & Bogatka & Banderola & & Komnata & Line 121 \\
\hline 0 & $6.24 \mathrm{~b}$ & $6.73 \mathrm{bc}$ & & $12.62 \mathrm{~d}$ & $18.87 \mathrm{~b}$ \\
20 & $4.72 \mathrm{~b}$ & $4.14 \mathrm{c}$ & & $18.31 \mathrm{c}$ & $17.33 \mathrm{~b}$ \\
40 & $6.66 \mathrm{~b}$ & $5.50 \mathrm{bc}$ & & $22.65 \mathrm{ab}$ & $18.07 \mathrm{~b}$ \\
70 & $7.05 \mathrm{~b}$ & $4.31 \mathrm{c}$ & & $20.51 \mathrm{~b}$ & $24.09 \mathrm{a}$ \\
100 & $6.61 \mathrm{~b}$ & $12.46 \mathrm{a}$ & & $19.35 \mathrm{bc}$ & $21.34 \mathrm{ab}$ \\
125 & $14.24 \mathrm{a}$ & $11.90 \mathrm{a}$ & & $24.40 \mathrm{ab}$ & $18.23 \mathrm{~b}$ \\
150 & $8.28 \mathrm{~b}$ & $7.94 \mathrm{~b}$ & & $25.22 \mathrm{a}$ & $17.75 \mathrm{~b}$ \\
\hline
\end{tabular}

Means $(n=10)$ within each column marked with the same letters do not differ statistically according to multiple range Duncan's test $(p<0.05)$

rate in leaves of both durum cultivars was the same as in leaves of 'Bogatka' and higher than in 'Banderola'. Probably the reason for this is the fact that in both $T$. durum cultivars photosynthetic apparatus was less injured by salt stress (which was documented by some chlorophyll fluorescence parameters), and natural $P_{\mathrm{N}}$ level in the control plants was higher than in T. aestivum cultivars.

\section{Electrolyte leakage}

The control plants of both species differed significantly in their natural cell membrane permeability (Table 6). Durum cultivars demonstrated a 2-3times higher electrolyte leakage from leaves than both bread wheat cultivars. Salinity increased EL in all plants under study. In 'Banderola', the highest ion leakage was observed at 100 and $125 \mathrm{mM}$ of $\mathrm{NaCl}$ (an increase by $45 \%$ in relation to the control), while in 'Bogatka' it was observed at $125 \mathrm{mM}(57 \%)$. In the case of 'Komnata', an increasing ion leakage under a rising salt concentration was observed, and finally at $150 \mathrm{mM}$ of $\mathrm{NaCl}$ it was twofold higher than in the control. Line 121 demonstrated the highest cell membrane permeability at 70 and $100 \mathrm{mM}$ of $\mathrm{NaCl}$ (an increase in relation to the control amounted to 22 and $12 \%$, respectively). In all cultivars, with the exception of 'Komnata', the highest ion leakage was observed not only in the highest applied salt doses but in concentrations in the range of $70-125 \mathrm{mM}$. In 'Banderola' and 'Komnata', a negative correlation between EL and RWC was found ( $r=-0.77$ and $r=-0.76 ; p<0.05$, respectively), what means that an increase in cell membrane permeability caused a decrease in water content calculated per $\mathrm{g}$ of DW. A negative influence of an increase in EL on FW was proved only for 'Komnata' plants ( $r=$ $-0.76 ; p<0.05)$.

\section{Proline content}

Control plants of both durum cultivars contained about a 2-2.5 times greater proline amount than the studied cultivars of bread wheat (Table 7). In the case of 'Bogatka', the highest amount of this amino acid was observed in a salinity of $125 \mathrm{mM}$, while in 'Banderola' it was only at $20 \mathrm{mM}$ of $\mathrm{NaCl}$. 'Komnata' plants contained the highest level of proline at $70 \mathrm{mM}$, while plants of line 121 at 125 , and $150 \mathrm{mM}$ of $\mathrm{NaCl}$. In summary, the pattern of proline amount change under salinity was similar for both 'Bogatka' and line 121, and for both 'Banderola' and 'Komnata'. This result suggests that proline accumulation as a defence response to salt stress is specific for the cultivar, not for wheat species. Only in the 'Bogatka' plants, a positive correlation between proline content and $P_{\mathrm{N}}$ was found $(r=0.88 ; p<0.05)$. The proline content in tissue correlated with RWC in 'Banderola', 'Komnata' and line 
121 ( $r$ coefficient amounted to $0.79,0.76$ and 0.87 at $p<0.05$, respectively). These results evident confirm protection role of this osmolyte against tissue dehydration in most wheat plant grown in saline soil.

Fresh and dry mass and relative water content

Salinity stress decreased FW in all the studied cultivars (Table 8). In 'Bogatka' and 'Banderola', the reduction of FW was observed at $70 \mathrm{mM}$ and at higher concentrations of $\mathrm{NaCl}$. Fresh mass decreased in 'Komnata' at $100 \mathrm{mM}$, while in line 121 gradually from $20 \mathrm{mM}$. A salt concentration of $150 \mathrm{mM}$ caused a decline of $\mathrm{FW}$ amounting to $50,36,48$, and $66 \%$ in the 'Bogatka', 'Banderola', 'Komnata' and line 121, respectively. A considerable decrease in DW was closely associated with the decrease in FW in the case of all plants. Salt concentration of $150 \mathrm{mM}$ caused the strongest DW reduction in line 121 (it amounted to $38 \%$ ), while the lowest DW lost was noted in the case

Table 7 Proline content ( $\mathrm{mg} \mathrm{g}^{-1} \mathrm{DW}$ ) in the leaves of T. aestivum and $T$. durum cultivars grown in soil treated with salt solutions of concentrations in the range of $0-150 \mathrm{mM}$

\begin{tabular}{llllll}
\hline $\mathrm{NaCl}(\mathrm{mM})$ & \multicolumn{2}{l}{ T. aestivum } & & \multicolumn{2}{l}{ T. durum } \\
\cline { 2 - 3 } \cline { 5 - 6 } \cline { 5 - 6 } & Bogatka & Banderola & & Komnata & Strain 121 \\
\hline 0 & $2.07 \mathrm{~b}$ & $1.98 \mathrm{~b}$ & & $4.20 \mathrm{bc}$ & $5.55 \mathrm{a}$ \\
20 & $2.62 \mathrm{ab}$ & $3.15 \mathrm{a}$ & & $5.36 \mathrm{~b}$ & $3.41 \mathrm{~b}$ \\
40 & $2.56 \mathrm{ab}$ & $1.59 \mathrm{bc}$ & & $3.40 \mathrm{c}$ & $2.90 \mathrm{~b}$ \\
70 & $1.99 \mathrm{~b}$ & $2.02 \mathrm{~b}$ & & $6.03 \mathrm{a}$ & $1.83 \mathrm{~d}$ \\
100 & $2.47 \mathrm{ab}$ & $1.82 \mathrm{~b}$ & & $2.71 \mathrm{c}$ & $2.34 \mathrm{bc}$ \\
125 & $3.22 \mathrm{a}$ & $1.32 \mathrm{c}$ & & $2.83 \mathrm{c}$ & $5.43 \mathrm{a}$ \\
150 & $2.23 \mathrm{~b}$ & $1.55 \mathrm{bc}$ & & $2.86 \mathrm{c}$ & $5.17 \mathrm{a}$ \\
\hline
\end{tabular}

Means $(n=7)$ within each column marked with the same letters do not differ statistically according to multiple range Duncan's test $(p<0.05)$ of 'Banderola' (13\%). Plants of 'Bogatka' and 'Komnata' showed a decline of this parameter amounting to about $30 \%$. In the case of all studied cultivars except 'Bogatka', a reduction of DW correlated significantly with $P_{\mathrm{N}}$ limitation ( $r=0.33,0.38$ and 0.34 at $p<0.05$ for 'Banderola', 'Komnata' and line 121, respectively). It is worth to add, that only for line 121 a correlation between energy dissipation in PSII (DIo/CSm) and FW $(r=-0.52 ; p<0.05)$ and DW ( $r=-0.47 ; p<0.05$ ) was found.

Relative water content declined under increasing salinity in all the cultivars (Table 8). The reduction of this parameter at $150 \mathrm{mM}$ in 'Banderola', 'Komnata' and line 121 amounted to $30 \%$, whereas in 'Bogatka' to $40 \%$. In the case of the latter, the first symptoms of water loss were already observed at $20 \mathrm{mM}$, while in 'Banderola' at $100 \mathrm{mM}$, in 'Komnata' at $70 \mathrm{mM}$, and in line 121 at $40 \mathrm{mM}$. Taking into account the changes in DW and RWC, 'Banderola' differs significantly from the other cultivars under study and seems to be more salt tolerant.

\section{Discussion}

Caryopses of both durum cultivars were germinated in the $\mathrm{NaCl}$ solutions of $0-250 \mathrm{mM}$. The 'Banderola' cultivar of T. aestivum showed a little (however statistically significant) decrease in caryopses germination already at $20 \mathrm{mM}$, whereas 'Bogatka' only at 200 and $250 \mathrm{mM}$ of $\mathrm{NaCl}$. Thus, germination ability under salt stress depends on cultivar specificity and not plant species. This conclusion confirms the earlier results of Noori and McNeilly (2000) who found that reduction of root and shoot length of $T$. durum plants under $100 \mathrm{mM} \mathrm{NaCl}$ depended on genotype. Rawat et al. (2011) observed a decrease in the germination rate of T. aestivum caryopses in soil with a salt concentration of 0-60 mM, while $\mathrm{Hu}$ et al. (2012) noted this effect at

Table 8 Fresh $(\mathrm{g})$ and dry $(\mathrm{g})$ weight and relative water content $\left(\mathrm{g} \mathrm{H}_{2} \mathrm{O} \mathrm{g}{ }^{-1}\right.$ of DW) of seedlings of T. aestivum and T. durum cultivars grown in soil treated with salt solutions of concentrations in the range of $0-150 \mathrm{mM}$

\begin{tabular}{|c|c|c|c|c|c|c|c|c|c|c|c|c|}
\hline \multirow[t]{3}{*}{$\mathrm{NaCl}(\mathrm{mM})$} & \multicolumn{6}{|c|}{ T. aestivum } & \multicolumn{6}{|c|}{ T. durum } \\
\hline & \multicolumn{3}{|c|}{ Bogatka } & \multicolumn{3}{|c|}{ Banderola } & \multicolumn{3}{|c|}{ Komnata } & \multicolumn{3}{|c|}{ Line 121} \\
\hline & FW & DW & RWC & FW & DW & RWC & FW & DW & RWC & FW & DW & RWC \\
\hline 0 & $10.40 \mathrm{a}$ & $1,13 \mathrm{a}$ & $8.20 \mathrm{a}$ & $11.4 \mathrm{a}$ & $1.23 \mathrm{a}$ & $8.27 \mathrm{a}$ & $9.71 \mathrm{a}$ & $1.10 \mathrm{a}$ & $7.83 a$ & $11.5 \mathrm{a}$ & $1.18 \mathrm{a}$ & $8.75 a$ \\
\hline 20 & $10.20 \mathrm{a}$ & $1.10 \mathrm{a}$ & $7.35 b$ & $12.0 \mathrm{a}$ & $1.36 \mathrm{a}$ & $7.82 \mathrm{a}$ & $8.69 \mathrm{a}$ & $1.01 \mathrm{a}$ & $7.60 \mathrm{a}$ & $8.84 \mathrm{~b}$ & $0.96 a b$ & $8.21 \mathrm{ab}$ \\
\hline 40 & $9.44 \mathrm{a}$ & $1.20 \mathrm{a}$ & $6.87 \mathrm{c}$ & $9.92 \mathrm{ab}$ & $1.20 \mathrm{a}$ & 7.27ab & 7.74ab & $0.98 \mathrm{a}$ & $6.90 \mathrm{ab}$ & $7.78 b c$ & $0.94 \mathrm{ab}$ & $7.28 b$ \\
\hline 70 & $5.98 \mathrm{~b}$ & $0.79 b$ & $6.57 \mathrm{c}$ & $7.27 \mathrm{~b}$ & $0.88 \mathrm{~b}$ & $7.26 \mathrm{ab}$ & $6.79 \mathrm{ab}$ & $0.95 \mathrm{a}$ & $6.15 b$ & $5.33 c$ & $0.65 b$ & $7.20 \mathrm{~b}$ \\
\hline 100 & $5.96 \mathrm{~b}$ & $0.86 b$ & $5.93 \mathrm{~cd}$ & $8.39 \mathrm{ab}$ & $1.19 \mathrm{a}$ & $6.05 \mathrm{~b}$ & $5.02 \mathrm{~b}$ & $0.76 \mathrm{~b}$ & $5.61 \mathrm{~b}$ & $4.99 \mathrm{c}$ & $0.68 \mathrm{~b}$ & $6.34 \mathrm{c}$ \\
\hline 125 & $5.56 \mathrm{~b}$ & $0.81 \mathrm{~b}$ & $5.62 \mathrm{~d}$ & $7.68 b$ & $1.09 \mathrm{a}$ & $5.97 \mathrm{~b}$ & $5.01 \mathrm{~b}$ & $0.76 \mathrm{~b}$ & $5.58 \mathrm{~b}$ & $5.01 \mathrm{c}$ & $0.71 \mathrm{~b}$ & $6.15 c$ \\
\hline 150 & $5.27 \mathrm{~b}$ & $0.79 b$ & $4.98 \mathrm{~d}$ & $7.36 \mathrm{~b}$ & $1.07 \mathrm{a}$ & $5.88 \mathrm{~b}$ & $5.04 \mathrm{~b}$ & $0.78 \mathrm{~b}$ & $5.46 \mathrm{~b}$ & $5.03 c$ & $0.73 b$ & $5.89 \mathrm{c}$ \\
\hline
\end{tabular}

Means $(n=15)$ within each column marked with the same letters do not differ statistically according to multiple range Duncan's test $(p<0.05)$ $F W$ fresh weight, $D W$ dry weight, $R W C$ relative water content 
0-200 mM of NaCl. Brini et al. (2009) found a significant decrease of caryopses germination of durum wheat under $200 \mathrm{mM}$ of $\mathrm{NaCl}$ treatment. It is very interesting that germination ability in salt solutions is negatively correlated with seedling growth. Coleoptile length of both durum cultivars was the most reduced compared to both studied cultivars of bread wheat. So, durum cultivars are more tolerant to salinity at the germinating stage, while bread wheat ones are more salt tolerant in the seedling stage. This effect could be explained by stronger selection seeds of bread wheat, resulted in development of seedlings with higher vigour compared to durum ones.

In general, salinity levels applied in our work did not evoke a disturbance of PSII efficiency. The cultivars of T. aestivum showed the highest values of the most studied parameters of chlorophyll fluorescence at $70 \mathrm{mM}$ of $\mathrm{NaCl}$, while cultivars of $T$. durum at a much higher level i.e., $150 \mathrm{mM}$. Moradi and Ismail (2007) have stated that plant tolerance to salinity may be demonstrated by a higher dissipation of excess energy. The $T$. durum plants showed a greater ability for excess energy dissipation as a response to salinity than the $T$. aestivum ones; however, in line 121 a negative correlation between fresh weight, dry weight and DIo/CSm was found, which means that the changes in plant mass did not depend on high excess of energy. An increase in dissipation of excess energy could also indicate damage to the photosynthetic apparatus, and therefore the interpretation of changes in the values of this parameter is ambiguous (Kalaji et al. 2011). Analysis of chlorophyll fluorescence parameters, especially of $\mathrm{PI}_{(\mathrm{CSm})}$ and $F_{\mathrm{v}} / F_{\mathrm{m}}$ in both studied wheat species suggests that the light phase of photosynthesis was not disturb under salinity. The results obtained in the presented study have found that this phase is more salt resistant than the subsequent stages of photosynthesis as well as transport and deposition of assimilates, which decide about plant mass production. This means, that under salt stress some processes of the light phase protect photosystems against excess of unused light.

A decrease of $P_{\mathrm{N}}$ in both bread and durum wheat under salt stress was closely connected with stomata closure. The decline in $P_{\mathrm{N}}$ under salinity proceeded in all the studied cultivars, but the reduction was the most visible in T. durum plants. Plants of 'Bogatka' demonstrated only $4 \%$ reduction of $P_{\mathrm{N}}$ rate with simultaneously the lowest reduction of $\mathrm{E}$ and $\mathrm{g}_{\mathrm{s}}$ compared to other cultivars under study. It is worth to mark that in 'Bogatka' no correlation between DW and $P_{\mathrm{N}}, E$ and $g_{\mathrm{s}}$ was found, while plants of other cultivars demonstrated significant association between DW and $P_{\mathrm{N}}$ rate. 'Banderola' showed the lowest DW reduction under salinity compared to the another. Sharma et al. (2005) observed a decrease of $P_{\mathrm{N}}, E$ and $g_{\mathrm{s}}$ in wheat genotypes under the influence of $\mathrm{NaCl}$ applied in the concentration adequate to $4-8 \mathrm{dS} \mathrm{m}^{-1}$. These authors stated that a reduction in the above-mentioned parameters was higher in salt sensitive genotype than in salt tolerant ones. Muranaka et al. (2002) observed that $100 \mathrm{mM} \mathrm{NaCl}$ inhibited the growth of $T$. aestivum plants, and this phenomenon was connected with a decrease in $P_{\mathrm{N}}$ and was evoked by a water deficit rather than the toxic influence of ions.

Stomata closure is a part of a plant's defence mechanism against salinity stress. A decrease in transpiration rate can help to conserve water and limit salt loading in the plant (Romero-Aranda et al. 2001). In our study, durum cultivars demonstrated a stronger reduction in $E$ and $g_{\text {s }}$ compared to bread wheat plants, which may indicate that the durum cultivars cope better under drought conditions. On the other hand, these cultivars demonstrated a greater limitation in $P_{\mathrm{N}}$ than the bread wheat ones. The lowest limitation of $P_{\mathrm{N}}$ under $150 \mathrm{mM} \mathrm{NaCl}$ was observed in 'Bogatka', showing simultaneously the lowest decline in $\mathrm{E}$ and the highest water loss, which suggests inhibition of water uptake by the root system. Hence, DW and RWC seem to be the most important parameters indicating a degree of plant sensitivity to salinity. Taking this into account, 'Banderola' could be recognized as more salt resistant compared to the other cultivars under study.

To the physiological parameters measured during salt stress belongs electrolyte leakage from the leaf cells as an indicator of cell membrane permeability (Ashraf and Harris 2004; Sairam and Tyagi 2004). Khatkar and Kuhad (2000) observed a gradual increase in the EL from bread wheat leaves under influence of $\mathrm{NaCl}$ applied in the range of 0-200 mM. In the studied wheat plants any serious damage of membrane structures based on the ion leakage measurements was observed. The significant increase in membrane permeability was found at different salt levels for each cultivar. It is interesting that the $\mathrm{NaCl}$ concentration of $150 \mathrm{mM}$, caused a similar ion leakage from leaf cells as in the control plants. Percentage electrolyte leakage correlated with RWC in 'Banderola' and 'Komnata', what means that in these both cultivars an increase in membrane permeability decreased tissue hydration. In addition, in 'Komnata', a negative influence of rising ion leakage on fresh mass production was found.

To the compounds most commonly accumulated under osmotic stresses belongs proline (Flowers et al. 1977). Khatkar and Kuhad (2000) as well as Khan et al. (2009) observed a strong increase in proline content in wheat plants grown at moderate salinity. In the present investigation, control plants of durum cultivars were characterized by a twofold higher proline content compared to the bread wheat ones. The proline level in the leaves of both wheat species changed non-specifically. However, it is interesting that the pattern of proline changes under salinity was similar for the cultivars rather than for particular species. 
The content of proline under the increasing salinity correlated with changes of RWC in 'Banderola', 'Komnata' and line 121. This result may imply protective role of proline against tissue dehydration in most wheat plants under salt stress.

\section{Conclusion}

Collating all the results obtained, we can state that the differences between genotypes can dominate over the differences between both analyzed species. In our opinion, the common statement that durum cultivars are more sensitive to salinity than bread wheat ones, is not quite right. A choice of one or two parameters, which clearly could be used for selection of salt tolerant plants is problematic. The ability to germinate in saline soil is a fundamental feature deciding salt tolerance. Percentage of germinated seeds and coleoptile growth are the indicators at the first stage of plant development. In the further stage, an increase in dry weight of plants seems to be the most important, so in our opinion these parameters should be used for plant selection. Taking into account the changes of DW and RWC under rising salinity, bread wheat cultivar 'Banderola' could be recognized as more salt tolerant. The degree of salinity tolerance of bread wheat 'Bogatka' is the same as durum line 121, while durum 'Komnata' is the most salt sensitive.

Author Contribution Agnieszka Płażek was the main contractor of the experiments, wrote the manuscript and interpreted data; Maria Tatrzańska, Maciej Maciejewski, Janusz Kościelniak, and Krzysztof Gondek performed analyses, Jarosław Bojarczuk is a breeder and author of used durum wheat cultivars; Franciszek Dubert designed and coordinated the study.

Acknowledgments The study was supported by the Polish Ministry of Science and Higher Education. No. 813/N-COST/2010/0 (within COST Action FA0901).

Open Access This article is distributed under the terms of the Creative Commons Attribution License which permits any use, distribution, and reproduction in any medium, provided the original author(s) and the source are credited.

\section{References}

Ashraf M, Ali Q (2008) Relative membrane permeability and activities of some antioxidant enzymes as the key determinants of salt tolerance in canola (Brassica napus L.). Environ Exp Bot 63:266-273

Ashraf M, Harris PJC (2004) Potential biochemical indicators of salinity tolerance in plants. Plant Sci 166:3-16

Bates LE, Waldren RP, Teare ID (1973) Rapid determination of free proline for water stress studies. Plant Soil 39:205-207
Brini F, Amara I, Feki K, Hanin M, Khoudi H, Masmoudi K (2009) Physiological and molecular analyses of seedlings of two Tunisian durum wheat (Triticum turgidum L. subsp. Durum [Desf.] varieties showing contrasting tolerance to salt stress. Acta Physiol Plant 31:145-154

Filek M, Walas S, Mrowiec H, Rudolphy-Skórska E, Sieprawska A, Biesaga-Kościelniak J (2012) Membrane permeability and micro- and macroelement accumulation in spring wheat cultivars during the short-term effect of salinity- and PEG-induced water stress. Acta Physiol Plant 34:985-995

Flowers TJ, Troke PF, Yeo AR (1977) The mechanism of salt tolerance in halophytes. Annu Rev Plant Physiol 28:89-121

Greenway H, Munns R (1980) Mechanism of salt tolerance in non halophytes. Annu Rev Plant Physiol 31:149-190

Hoagland DR, Arnon DI (1938) The water-culture method for plants without soil. University of California Agricultural Experiment Station Circular 347:29-32

Hu M, Shi Z, Zhang Z (2012) Effects of exogenous glucose on seed germination and antioxidant capacity in wheat seedlings under salt stress. Plant Growth Regul 68:177-188

Hura T, Hura K, Grzesiak M (2007) Effect of long-term drought stress on leaf gas exchange and fluorescence parameters in $C_{3}$ and $C_{4}$ plants. Acta Physiol Plant 29:103-113

Kalaji HM, Govindjee, Bosa K, Kościelniak J, Żuk-Gołaszewska K (2011) Effects of salt stress on photosystem II efficiency and $\mathrm{CO}_{2}$ assimilation of two Syrian barley landraces. Environ Exp Bot 73:64-72

Khan MA, Shirazi MU, Khan MA, Mujtaba SM, Islam E, Mumtaz S, Shereen AR, Ansari U, Ashraf MY (2009) Role of proline, K/Na ratio and chlorophyll content in salt tolerance of wheat (Triticum aestivum L.). Pak J Bot 41:633-638

Khatkar D, Kuhad MS (2000) Short-term salinity induced changes in two wheat cultivars at different growth stages. Biol Plant 43:629-632

Lazár D (1999) Chlorophyll $a$ fluorescence induction. BBA 1412:1-28

Mansour MMF (1998) Protection of plasma membrane of onion epidermal cells by glycinebataine and proline against $\mathrm{NaCl}$ stress. Plant Physiol Biochem 36:767-772

Martyniak L, Dạbrowska-Zielińska K, Szymczyk R, Gruszczyńska M (2007) Validation of satellite-derived soil-vegetation indices for prognosis of spring cereals yield reduction under drought conditions-case study from central-western Poland. Adv Space Res 39:67-72

Mitsuya S, Kawasaki M, Taniguchi M, Miyake H (2003) Light dependency of salinity-induced chloroplast degradation. Plant Prod Sci 6:219-223

Moradi F, Ismail AM (2007) Responses of photosynthesis, chlorophyll fluorescence and ROS-Scavenging system to salt stress during seedling and reproductive stages in rice. Ann Bot 99:1161-1173

Munns R, James R (2003) Screening methods for salinity tolerance: a case study with tetraploid wheat. Plant Soil 253:201-218

Munns R, Tester M (2008) Mechanism of salinity tolerance. Annu Rev Plant Biol 59:651-681

Munns R, Guo J, Passioura JB, Cramer GR (2000) Leaf water status controls daytime but not daily rates of leaf expansion in salttreated barley. Aust J Plant Physiol 27:949-957

Muranaka S, Shimizu K, Kato M (2002) Ionic and osmotic effects of salinity on single-leaf photosynthesis in tow wheat cultivars with different drought tolerance. Photosynthetica 40:201-207

Noori SAS, McNeilly T (2000) Assessment of variability in salt tolerance based on seedling growth in Triticum durum Desf. Genet Res Crop Evol 47:285-291

Paul MJ, Foyer CH (2001) Sink regulation of photosynthesis. J Exp Bot 52:1383-1400 
Rawat L, Singh Y, Shukla N, Kumar J (2011) Alleviation of the adverse effects of salinity stress in wheat (Triticum aestivum L.) by seed biopriming with salinity tolerant isolates of Trichoderma harzianum. Plant Soil 347:387-400

Romero-Aranda R, Soria T, Cuartero J (2001) Tomato plant-water uptake and plant-water relationships under saline growth conditions. Plant Sci 160:265-272

Sairam RK, Tyagi A (2004) Physiology and molecular biology of salinity stres tolerance in plants. Curr Sci 86:407-421

Schar C, Vidale PL, Luthi D, Frei C, Haberli C, Liniger MA, Appenenzeller C (2004) The role of increasing temperature variability in European summer heatwaves. Nature 427:332-336

Sharma N, Gupta NK, Gupta S, Hasegawa H (2005) Effect of $\mathrm{NaCl}$ salinity on photosynthesis rate, transpiration rate, and oxidative stress tolerance in contrasting wheat genotypes. Photosynthetica 43:609-613

Strasser RJ, Srivatava A, Tsimilli-Michael M (2000) The fluorescence transient as a tool to characterize and screen photosynthetics samples. In: Yunus M, Pathre U, Mohanty $\mathrm{P}$ (eds) Probing photosynthesis: mechanism, regulation and adaptation. Taylor and Francis, Bristol, pp 45-483

Walter J, Nagy L, Hein R, Rascher U, Beierkuhnlein C, Willner E, Jentsch A (2011) Do plants remember drought? Hints towards a drought-memory in grasses. Environ Exp Bot 71:34-40

Yasar F, Ellialtioglu S, Kusvuran S (2006) Ion and lipid peroxide content in sensitive and tolerant eggplant callus cultured under salt stress. Eur J Hortic Sci 71:169-172 